\title{
Novíssimas direitas e a política na era da pós-verdade: uma análise da guerra cultural
}

\author{
Newest rights and politics in the post-truth era: an analysis \\ of the cultural war
}

Nuevíssimas derechas e la política em la era de la
posverdad: un análisis de la guerra cultural

Recebido em 30-08-2020

Modificado em 01-01-2021

Aceito para publicação em 27-02-2021

\section{doi https://doi.org/10.47456/simbitica.v8i2.36384}

\section{Pablo Ornelas Rosa \\ ORCID: 0000-0002-9075-3895}

Doutor em ciências sociais pela Pontifícia Universidade Católica de São Paulo, com pós-doutorado em psicologia institucional e em saúde coletiva pela Universidade Federal do Espírito Santo e em sociologia pela Universidade Federal do Paraná. É professor da Universidade Vila Velha. E-mail: pablorosa13@ gmail.com

\section{Vitor Amorim de Ângelo \\ ORCID: 0000-0002-8550-9548}

Doutor em ciências sociais pela Universidade Federal de São Carlos, com estágio sanduíche no Institut DÉtudes Politiques de Paris e pós-doutorado em sociologia política pela Université de Paris Quest-Nanterre La Défense. É professor da Universidade Vila Velha. E-mail: vitor.angelo@uvv.br

\section{Tatiane Braga}

ORCID: 0000-0001-7057-389X

Mestre em sociologia política pela Universidade Vila Velha e bacharel em jornalismo pelas Faculdades Integradas São Pedro. É âncora do telejornal Bom Dia Espírito Santo, na TV Gazeta (TV Globo/ES). E-mail: tatianembraga@gmail.com

\section{Resumo}

O artigo resulta da articulação de duas pesquisas que tem como objetivo compreender a ascensão das novíssimas direitas brasileiras e as tecnologias utilizadas para difundir sua visão de mundo. Ao compreender que as primeiras décadas do século XXI estão sendo caracterizadas por novas formas de produção e difusão de informações proporcionadas pelo ciberespaço, fenômeno que levou o dicionário Oxford a trazer como palavra do ano em 2016 a pós-verdade, verificamos a necessidade de compreender a emergência de tradições políticas mais à direita, a exemplo dos neoconservadores, liberais-conservadores, liberais e libertários anarcocapitalistas. Desse modo, o artigo apresentado procurou analisar, a partir de uma pesquisa etnográfica, as formas de produção e difusão de seus discursos, bem como as estratégias de capilarização na política brasileira.

Palavras-chaves: Direita, novíssimos movimentos sociais, MBL, fake News. 


\section{Introdução}

A passagem do século XX para o XXI foi caracterizada, sobretudo, por transformações jamais experimentadas nas distintas sociedades que conhecemos por meio da literatura acadêmica reconhecida e isso certamente envolve o surgimento de novas formas de sociabilidade virtualizada, que emergem a partir daquilo que Manuel Castells (2000) versou como sociedade em rede. Essa afirmação pode ser evidenciada na medida em que constatamos a emergência de novas modalidades interacionais que escapam àquelas presentes nos séculos anteriores, recorrentemente caracterizadas pela interação face a face ou pelos meios de comunicação corporativos, mas que começaram a ocorrer através do uso de diferentes plataformas digitais que passaram a se apropriar das informações por nós disponibilizadas gratuitamente em nossos históricos de pesquisa, usando-as comercialmente com o propósito de modular o nosso comportamento não apenas no que se refere ao padrão de consumo, mas também acerca das nossas escolhas políticas (Lanier, 2018; Machado, 2018; Zuboff, 2019; Da Empoli, 2019; Rosa, 2019; Lazzaratto, 2019; Mello, 2020). Inclusive, esse fenômeno passou a ser compreendido, sobretudo a partir de 2016, como uma ameaça ou mesmo ruptura às democracias liberais mundo afora, conforme destacou Castells (2018).

No entanto, isso não quer dizer que as antigas formas de interação face a face ou mesmo a atuação dos grandes meios de comunicação corporativos tenham deixado de existir, tampouco que esse fenômeno seja determinante e universal, atingindo da mesma forma diferentes sujeitos e populações. O que estamos sugerindo, a partir da literatura apresentada, é que essa tendência passou a se intensificar paulatinamente, resultando no uso cada vez mais frequente de plataformas digitais que visam criar diferentes formas de engajamento, através de distintas técnicas de modulação comportamental, que também podem operar no campo da política, por meio do contágio orientado por discursos de ódio, conforme sustentou Dunker (2019:128) ao evidenciar os circuitos dos afetos negativos e segregativos nesse contexto, caracterizado pela interação virtualizada:

O risco maior para a democracia brasileira reside na emergência de discursos que se ajustam ao que Adorno chamou de síndrome fascista, cujo afeto dominante é o ódio segregativo. Aqui, a existência do outro, que não experimenta os mesmos valores e não goza da mesma maneira que "nós", torna-se uma ofensa perturbadora. É assim que ele deixa de ser um indivíduo singular e. passa a valer pelo grupo ao qual pertence e, finalmente, se desumaniza na massa uniforme. Venerar, supersticiosamente, um líder, uma atitude de submissão acrítica e estereotipada, é a contrapartida desse processo. Dessa forma, a excepcionalidade legítima se posiciona do lado do sujeito, autorizando a emergência de afetos segregativos contra a massa inimiga. Há uma redução dualista das pessoas, como líder-seguidor ou vencedorfracassado, bem como uma projeção essencialista do inimigo. Aqui, predomina a 
identificação de massa e uma espécie de ódio que age por contaminação. Por exemplo, se o PT tem casos de corrupção, as pessoas que simpatizam com ele são automaticamente defensoras da corrupção ou, até corruptas elas mesmas. A contiguidade do ódio passa do PT para o comunismo, daí para o esquerdismo, gênero, ideologia e disso para qualquer sintagma que contenha a expressão "social" (por isso o Partido Nacional Socialista de Hitler se torna automaticamente de esquerda).

Até o final do século XX, a maior parte da população era alvo passivo das informações difundidas pela grande mídia corporativa, ao passo que com a emergência da internet e, sobretudo, de plataformas digitais, como Youtube, Facebook, Instagram, Twitter, WhatsApp, Telegram, dentre outras formas possíveis que nasceram com a Web 2.0, deixamos de ser apenas receptores desses dados e fatos selecionados por jornais, rádios e canais de televisão - que no caso brasileiro operam por meio de concessões estatais, conforme ocorria em momentos precedentes -, na medida em que passamos a poder produzir e difundir conteúdos no ciberespaço não apenas para fins comerciais, mas também políticos.

Ao reconhecer que distintas técnicas algorítmicas e de modulação comportamental foram utilizadas através das plataformas digitais por candidatos populistas de extrema direita e parte de seus eleitores nas últimas eleições de diversos países, dentre eles, os Estados Unidos em 2016 e o Brasil em 2018, Da Empoli (2019) constatou que, enquanto a política, no contexto de hegemonia dos grandes meios de comunicação corporativos, tinha uma tendência centrípeta, ou seja, quanto mais diplomático e consensual fosse o discurso, maior seria o seu alcance; com emergência das plataformas digitais, como o Youtube, Facebook, Instagram, Twitter, WhatsApp e Telegram, passamos a encontrar a ascensão de um movimento contrário e, portanto, centrífugo, já que quanto mais polarizado e radical o discurso, maior o seu alcance. No entanto, é importante destacar que, do ponto de vista genealógico - tanto em termos nietzschianos quanto foucaultianos -, esse fenômeno deve ser tratado enquanto uma tendência, evitando, portanto, generalizações.

Assim, se por um lado essas novas modalidades infocomunicacionais que emergem no século XXI poderiam ser supostamente benéficas para as sociedades humanas, uma vez que possibilitariam uma maior qualidade, velocidade e liberdade na produção e difusão de conteúdos de forma mais democrática, além de horizontalizar o fluxo de circulação de notícias, inclusive promovendo outras formas de existência que passaram a ocorrer virtualmente; por outro, elas podem gerar uma enorme confusão na difusão de suas informações, já que se torna bastante difícil conferir sua veracidade, tendo em vista a insuficiência de filtros que garantam certa qualidade em sua circulação. A dificuldade em tratar da veracidade destas informações e fatos decorrentes da ausência ou escassez de filtros 
acerca destes dados, chamados hodiernamente de fact-checking ${ }^{1}$, passou não apenas a comprometer a qualidade do que é produzido e/ou difundido, como também permitiu o nascimento da chamada pós-verdade.

\begin{abstract}
Não por acaso, em 2016, o Oxford Dictionaries escolheu "pós-verdade" como sua palavra do ano, definindo-a como forma abreviada para "circunstâncias em que os fatos objetivos são menos influentes em formar opinião pública do que os apelos à emoção e à crença pessoal. Sua exata etimologia é contestada, embora haja um consenso geral de que foi utilizada pela primeira vez em 1992, na revista The National, em um artigo do escritor sérvio-norte-americano Steve Tesich. Segundo Tesich, os norte-americanos estavam tão traumatizados com Watergate, o caso IrãContras e outros escândalos, que começaram a dar as costas para a verdade e conspirar exaustivamente por sua supressão (D’Ancona, 2018:20).
\end{abstract}

A análise apresentada acerca do nascimento das novíssimas direitas e a política na era da pós-verdade foi desenvolvida inicialmente a partir do entendimento de Andrew Korybko (2015) sobre a chamada guerra híbrida, sendo utilizada posteriormente por Piero Leirner (2020) para tratar do caso brasileiro e os desdobramentos da política no século XXI, orientadas, principalmente, por uma espécie de guerra de quarta geração, travada não mais em territórios precisos e por meio de forças bélicas, mas enredada no espaço virtual, buscando alterar a percepção da população por meio de uma guerra de narrativas que se dá sob uma forma cognitiva e informacional. Desse modo, partiremos da compreensão de Paul Virilio (2005) acerca da relação entre a guerra e o cinema, tratando-a no tempo presente a partir da emergência das plataformas digitais, entendidas da mesma forma com que o autor relacionou ao cinema, ou seja, compreendendo que o "cinema entra para a categoria das armas a partir do momento em que está apto a criar a surpresa técnica ou psicológica” (Virilio, 2005:27).

Assim, ao entender que "a guerra é um sintoma delirante que funciona na meia-luz do transe, da droga, do sangue, da unanimidade que identifica em seu próprio corpo-a-corpo aliados e inimigos, vítimas e algozes" (Virilio, 2005:23), compreenderemos a era da pósverdade caracterizada como uma espécie de guerra informacional e cognitiva e, portanto, uma guerra intencional de quarta ou quinta geração, conforme destacou Leirner (2020:99). Ao tomar como referência o texto de William Lind (2001), Leiner (2020) acaba diferenciando as três primeiras gerações de guerra - guerra de massa, de poder de fogo e de manobra -,

\footnotetext{
${ }^{1} \mathrm{O}$ fact-checking é uma checagem de fatos, isto é, um confrontamento de histórias com dados, pesquisas e registros. Se um político jura que nunca foi acusado de corrupção, há registros judiciais que irão atestar se é verdade. Se o governo diz que a inflação diminuiu, é preciso checar nos índices se isso realmente ocorreu. E se uma corrente diz que há um projeto de lei para cancelar as eleições, é preciso conferir nas propostas em tramitação se essa informação é real. O fact-checking é uma forma de qualificar o debate público por meio da apuração jornalística. De checar qual é o grau de verdade das informações. Disponpivel em https://apublica.org/2017/06/truco-o-que-e-fact-checking/. Acesso no dia 13 de jun. 2018.
} 
evidenciando a emergência de uma quarta geração caracterizada pela computação e uma quinta ainda que se somaria a essa quarta, entendida como uma "guerra irregular", "assimétrica" e "não convencional", em que o termo "híbrido" seria o elemento que configuraria essa quinta geração, justamente porque utiliza a desinformação possível de ser difundida nas plataformas digitais como sua principal arma em busca de alterações psicológicas e cognitivas.

Ao procurar alterar a percepção da população brasileira por meio da crença na existência de uma suposta guerra cultural em curso no Brasil e no mundo, impetrada pela esquerda internacional que se apresenta sob a roupagem do globalismo, parece-nos plausível considerar que Olavo de Carvalho (2018) e aqueles que tomam sua narrativa como verdade ${ }^{2}$ situam suas ideias a partir daquilo que Korybko (2015) e Leirner (2020) entenderam por guerra híbrida, embora ainda seja tratada em outros termos. Desse modo, assim como Virilio (2005) tratou do cinema como uma categoria de armas na busca pela alteração da percepção da população, compreenderemos da mesma forma o uso político das plataformas digitais, pois segundo o autor,

Não existe guerra, portanto, sem representação, nem arma sofisticadas sem mistificação psicológica, pois, além de instrumentos de destruição, as armas são também instrumentos de percepção, ou seja, estimuladores que provocam fenômenos químicos e neurológicos sobre os órgãos do sentido e o sistema nervoso central, afetando as reações, a própria identificação dos objetos percebidos, sua diferenciação em relação aos demais etc. (Virilio, 2005:24).

Ao sustentar que "a guerra não pode jamais ser separada do espetáculo mágico, porque sua principal finalidade é justamente a produção deste espetáculo: abater o adversário é menos captura-lo do que cativá-lo, é infligir, antes da morte o pavor da morte" (Virilo, 2005:24), o autor nos permite compreender que tanto os diagnósticos do tempo presente quanto as estratégias políticas proferidas e utilizadas por integrantes do Movimento Brasil Livre - MBL e por Olavo de Carvalho, mesmo apresentando divergências em suas propostas e análises, podem ser compreendidas pela chave deste espetáculo político virtualizado, abarcando não apenas o fomento a discursos de ódio contra os dissidentes políticos, sobretudo

\footnotetext{
${ }^{2}$ Olavo de Carvalho é um formador de opinião brasileiro que reside nos Estados Unidos há alguns anos e atua veementemente nas redes sociais digitais, reconhecendo-se como escritor, jornalista e filósofo conservador. Embora não tenha uma formação acadêmica formal, ele atua em diversas plataformas digitais, comercializando seus livros e cursos (https://lp.seminariodefilosofia.org/) e também figurando publicamente como o mentor do atual presidente da república do Brasil, Jair Bolsonaro e os seus filhos, sendo uma referência também para alguns ministros deste governo, como Ernesto Araújo (Ministro das Relações Exteriores), Ricardo Vélez Rodriguez e Abraham Weintraub (Ministros da Educação) e Damares Alves (Ministra da Mulher, Família e dos Direitos Humanos), além de influenciar outros cargos importantes deste governo como aquele ocupado por Felipe Martins (Assessor Especial para Assuntos Internacionais), bem como orientar politicamente diversos parlamentares do país.
} 
de esquerda, mas também perpassando justamente a compreensão da existência de uma guerra de narrativas, na qual quem possui as melhores armas digitais obtém o sucesso e a vitória sobre o adversário, produzindo o discurso que reverberará enquanto verdade por mais falacioso que seja. Aqui também é importante reconhecer que o abate ao adversário, no contexto da guerra de quarta ou quinta geração, não perpassa necessariamente a morte física do inimigo, mas o seu extermínio simbólico, muitas vezes associado à ridicularização, persecução nas redes, humilhação e principalmente destruição de reputação.

\section{Das manifestações de junho de 2013 à ascensão do Bolsonarismo: uma guerra cultural}

Para compreendermos o Brasil pós-2018, caracterizado pela ascensão da extrema direita populista presente na gestão do presidente Jair Bolsonaro, é importante considerarmos não apenas as eleições presidenciais de 2014, que culminaram com a reeleição de Dilma Rousseff Também é necessário observarmos outros acontecimentos que permitiram com que ocorresse um declínio do PT e a emergência da coalizão de movimentos anti-esquerda, amparados em certo radicalismo econômico e moral, também associados à difusão de discursos ofensivos que passaram a circular nas plataformas digitais, a exemplo das narrativas agressivas recorrentemente proferidas por Olavo de Carvalho que passaram a ser utilizadas por demais indivíduos e grupos que se reconhecem como direitistas, como o Movimento Brasil Livre - MBL, conforme constatou Rocha (2018:18-19).

Dentre os fatos ocorridos que devem ser considerados na análise apresentada estão: o resgate da Lei de Segurança Nacional através da Lei Antiterrorismo (13.260/2016) ${ }^{3}$, retomada pela presidente que sofreu com essa legislação no período da ditadura civil-militar; a seletividade penal partidária e até mesmo a lawfare encontrada na Operação Lava Jato contra integrantes do PT; prisão do ex-presidente Lula (Zanin, Martins e Valim, 2019); criação de uma agenda nitidamente neoliberal pelo partido de seu vice Michel Temer, do PMDB, que culminou com a proposição do programa intitulado "Uma ponte para o Futuro" (Rosa, 2016); e, principalmente, a apropriação de técnicas de articulação política por parte de diferentes grupos com distintas pautas que se reconheciam como de direita e que passaram a ocupar as manifestações pela redução do valor no transporte público, capitaneadas pelo MPL e demais grupos autonomistas, permitindo certa capilarização discursiva através de memes criados e compartilhados em diversas plataformas digitais por grupos como o MBL (Gohn, 2018,

\footnotetext{
${ }^{3}$ Disponível em https://www12.senado.leg.br/noticias/materias/2016/03/18/lei-antiterrorismo-e-sancionada-comvetos-pela-presidente-dilma. Acesso no dia 05 de jan. 2021.
} 
Pinheiro-Machado, 2019), que teve três de seus principais integrantes entrevistados por nós Kim Kataguiri, Alexandre dos Santos e Arthur do Val, conhecido como "mamãe falei".

Contudo, o principal elemento que consideraremos nessa pesquisa, para além da importância dos fatos acima mencionados, é justamente a disputa por regimes de verdade decorrentes dessa guerra de narrativas que se apresenta no tempo presente, a partir daquilo que Olavo de Carvalho (2018), dentre outros, chamou de guerra cultural - e de guerra híbrida, se considerarmos os termos trazidos por Korybko (2015) e depois por Leirner (2020). Não obstante, é importante destacar que "uma das principais características dessa nova dinâmica é aquilo que podemos chamar de a grande inversão. Trata-se de um método dialético: uma constante projeção que certos agentes realizam nos seus inimigos invertendo suas posições (Leirner, 2020:18). Portanto, partiremos da hipótese de que a palavra ideologia acabou sendo encoberta por uma cortina de fumaça, tendo em vista que ela passa a assumir um tom de "conspiração", pertencendo sempre aos "outros", aos dissidentes políticos, sobretudo de esquerda.

\begin{abstract}
A grande inversão está em todo o lugar hoje. A Rede Globo se tornou uma agente do comunismo internacional. O PT tem um "projeto gramsciano" de dominação cultural, diz Olavo de Carvalho, o não-ideológico. "As ONGs tocam fogo na Amazônica". Bolsonaro afirma que as urnas estão fraudadas. O powerpoint de Deltan Dallagnol mais parece um organograma do Ministério Público e sua relação com Sérgio Moro - só trocaram os nomes nos quadrinhos. Os militares são "técnicos" que ocupam despretensiosamente mais de 1000 cargos só no Palácio do Planalto, mais de $1 / 3$ do total e quem aparelha o Estado é o PT. As universidades estão inteiramente infestadas de ideologia, segundo os cientistas da Terra Plana. Para que uma inversão chegue a qualquer um de nós é fácil. Pois, como estamos percebendo, o problema não é só o Ministro, mas o "guarda da esquina", como já alertava o Vice-Presidente Pedro Aleixo, em 1968 quando da decretação do AI-5 (Leirner, 2020:19).
\end{abstract}

No entanto, para compreendermos esses acontecimentos recentes, bem como os seus desdobramentos que culminaram com a vitória de Bolsonaro nas eleições brasileiras de 2018, é importante reconhecermos que "a disputa por agendas políticas no século XXI se constrói por meio de uma guerra que é fundamentalmente discursiva, ou seja, se baseia em palavras e símbolos" (Pinheiro-Machado, 2019:82) e tem sido travada por meio de narrativas produzidas e difundidas por plataformas digitais, que no caso brasileiro contou principalmente com o WhatsApp, conforme constatou Mello (2019).

Tudo isso faz do WhatsApp um veículo assustadoramente eficiente para disseminar propaganda política - ou desinformação. Segundo pesquisa encomendada pelo Senado ${ }^{4}$ e publicada em novembro de 2019 , $79 \%$ dos brasileiros usam sempre o

\footnotetext{
${ }^{4}$ Disponível em https://www12.senado.leg.br/radio/1/noticia/pesquisa-aponta-que-whatsapp-e-a-principal-fontede-informacao-de-79-dos-entrevistados. Acesso no dia 31 de dez. 2020.
} 
WhatsApp como fonte de informação mais importante. A TV é a principal fonte de informação para 50\% dos brasileiros, seguida do YouTube (49\%), Facebook (44\%), sites de notícias $(38 \%)$ e rádio $(22 \%)$. Os jornais constituem a fonte primordial de informação de apenas $8 \%$ dos brasileiros, na frente apenas do Twitter (7\%) (Mello, 2019:33-34).

Desse modo, as manifestações ocorridas no Brasil em junho de 2013 ressaltam a emergência dessa guerra cognitiva e informacional, mencionada por diversos autores, dentre elas Gohn (2018) e Pinheiro-Machado (2019), tendo em vista que esses eventos nasceram com Movimento Passe Livre - MPL, que se colocava no espectro à esquerda da política nacional, reivindicando ora a redução do valor no transporte coletivo, ora a gratuidade deste serviço público para os estudantes, mas tendo suas estratégias de articulação capturadas por grupos de direita, a exemplo do Movimento Brasil Livre - MBL e outros demais que se reconhecem como liberais, conservadores ou mesmo conservadores-liberais. Assim, diversas técnicas políticas utilizadas pelas mídias independentes que antes eram características de movimentos de esquerda autonomistas e anticapitalistas, acabaram sendo capturadas e usadas como instrumentos ainda mais articulados pelas direitas em seu uso nas distintas plataformas digitais, espaços que passaram não apenas a habitar, mas a atuar incessantemente através da mobilização de afetos negativos e segregativos contra o nem tão novo bode expiatório: os dissidentes esquerdistas.

As manifestações de junho de 2013 não foram as únicas pioneiras na utilização dos meios digitais para disseminar ideias políticas através da articulação de manifestações e isso pode ser encontrado nas análises de Tognozzi (2014), que elencou várias mobilizações populares que contaram com as redes. Dentre elas, podemos citar, ainda no início do século XXI, em 2002, nas Filipinas, um evento organizado através de troca de mensagens de celular por um grupo de jovens que, após cinco dias de protesto, conseguiu articular a renúncia do presidente acusado de corrupção, Joseph Estrada. Já entre os mais recentes, atentamos que foram mesmo as redes sociais, não apenas o meio digital, que fortaleceram as ações, como no caso da Primavera Árabe, em 2010, quando teve início uma onda de manifestações que se espalhou pelo mundo árabe com motivos que variavam do autoritarismo político à crise econômica. Outro movimento de repercussão que merece destaque foi o Occupy Wall Street, em 2011, manifestando-se contra as instituições financeiras num momento de grave crise econômica. Desse modo, os protestos não só eram organizados, mas também transmitidos através de celulares e laptops para todo o planeta.

Portanto, as jornadas de junho de 2013, assim como as tantas outras manifestações que se seguiram em diversas cidades brasileiras nos anos subsequentes, inauguraram uma 
transformação paradigmática acerca da circulação de informações e capacidade de mobilização social através do ciberespaço, permitindo com que as novíssimas direitas também chamadas por Gohn (2018:120) de organizações movimentalistas ${ }^{5}$ - emergissem impetuosamente através de um domínio muito maior no que se refere ao funcionamento preciso das plataformas digitais, bem como suas técnicas de produção e difusão de conteúdo.

Como o texto apresentado não versará especificamente sobre as manifestações de junho de 2013 no Brasil, tampouco sobre a Primavera Árabe e outros demais acontecimentos mencionados anteriormente, mas sobre a incidência de desinformação no campo da política deste país, esses eventos serão citados exclusivamente para exemplificar o fenômeno investigado, dando um panorama acerca da complexidade de elementos que envolve essa rearticulação das direitas em termos contrarrevolucionários.

Desse modo, embora essas manifestações ocorridas em diversas cidades brasileiras, no ano de 2013, antecedam o nascimento formal da chamada pós-verdade, a partir de sua exposição pelo dicionário Oxford como palavra do ano em 2016, partiremos do entendimento de que foi por meio destes protestos que se tornou possível compreender a emergência das forças políticas à direita, que passaram a ocupar um lugar significativo e até mesmo determinante na democracia brasileira, possibilitando, inclusive, o seu comprometimento através da produção e difusão de informações falaciosas que passaram a disputar a condição de verdade.

É justamente sob esse perfil, encontrado em parte das abordagens das distintas direitas brasileiras, recorrentemente situado como liberais, conservadores e/ou conservadores-liberais, que tomam como ponto de partida as pautas morais encontradas na agenda de grupos conservadores e a defesa do livre mercado defendida pelos economistas liberais e neoliberais, que teremos um caminho trilhado em direção à coalizão de diferentes forças políticas, possibilitando uma virada antidemocrática na democracia liberal brasileira, iniciada com a redemocratização, ocorrida a partir de 1988. Essa articulação, que contempla diferentes gradações das direitas, contou com a aproximação de defensores do livre mercado e do tradicionalismo das mais distintas cepas, passando de tributários dos conservadorismos

\footnotetext{
${ }^{5}$ Segundo Gohn (2018:120), “Organizações movimentalistas é uma terminologia que criamos para caracterizar grupos de jovens que se aglutinam ao redor de alguns líderes ou formadores de opinião, os quais elaboram um plano de atividades e o executam sob a ótica de uma corporação. Como exemplo citamos o "Vem Pra Rua" e o MBL (Movimento Brasil Livre) entre outros, tratados abaixo. Eles tiveram importância capital na convocação das megamanifestações de rua no Brasil, em 2015 e 2016. Seus fundamentos são de inspiração liberal, buscam influenciar a opinião pública via a defesa de alguns lemas e bandeiras, como o ataque a corrupção. Apresentamse como sendo portadores da renovação no campo das práticas políticas, contam com o apoio de grupos empresariais e criam ou apoiam entidades voltadas para o que denominam empoderamento de jovens".
} 
cristãos, integralistas, monarquistas, militares e, sobretudo, olavistas, abarcando até mesmo os defensores veementes das escolas econômicas austríacas e de Chicago.

Portanto, foi principalmente a partir desse contexto, iniciado com as manifestações de 2013, que verificaremos o nascimento de novas narrativas estranhas ao campo acadêmico hegemônico, que passaram a se utilizar daquilo que Leirner (2020) chamou de a grande inversão, associando as esquerdas ao comunismo, socialismo, globalismo e, sobretudo, ao petismo, entendidos agora como os grandes inimigos do país. Essa compreensão que inverte, ou mesmo subverte a realidade, conseguiu fazer com que as direitas brasileiras se reorganizassem em torno da articulação de pautas morais e econômicas, uma vez que "após as mobilizações das Jornadas de Junho de 2013, a crise se constituiu uma janela de oportunidades políticas a mobilização de muitos jovens secundaristas nos anos seguintes" (Pinheiro-Machado; Scalco, 2018:59).

Foi justamente isso que constatamos através da pesquisa de campo realizada por nós em eventos do MBL a partir de 2017. Quando perguntamos aos seus integrantes, por exemplo, sobre os seus posicionamentos políticos, econômicos e morais, bem como acerca da relevância de Olavo de Carvalho na constituição de suas visões de mundo, a resposta recorrente que tivemos reiterava nossa hipótese, que presumia uma coalizão das direitas, orientadas principalmente pelos diagnósticos sobre o tempo presente apresentados inicialmente por Olavo de Carvalho (2018), mas reconhecidos e legitimados por outros demais grupos, não apenas a exemplo do MBL, conforme constatamos em nossas entrevistas com seus integrantes, mas também por militares ${ }^{6}$, conforme podemos visualizar no seguinte trecho encontrado no livro A verdade sufocada: A história que a esquerda não quer que o Brasil conheça, escrito por Carlos Alberto Brilhante Ustra (2018), o único representante das Forças Armadas do Brasil condenado por tortura no período da ditadura civil-militar brasileira $^{7}$. Inclusive, é importante mencionar que o próprio presidente Jair Bolsonaro já chegou a afirmar que este seria o seu livro de cabeceira, além de ter em cima de sua mesa, em

\footnotetext{
${ }^{6}$ É importante destacar que, embora tenha realizado diversas palestras para todo o meio militar brasileiro, sobretudo, nos anos 1990, influenciando fortemente essa instituição com uma narrativa anti-comunista pósGuerra Fria e servindo de arcabouço teórico para recontar legitimamente a história da ditadura civil-militar brasileira sob a ótica dos violentadores, Olavo de Carvalho foi paulatinamente se tornando crítico das forças armadas do país na medida em que passou a argumentar que elas perseguiram o alvo errado, pois ao invés de combater a revolução cultural gramsciana que supostamente acontecia nas universidades e nos meios de comunicação corporativos daquele período, os militares foram atrás dos guerrilheiros que impetravam uma luta armada e que, portanto, não produziam nenhuma ameaça ao país (Carvalho, 2018:327).

${ }^{7}$ Disponível em http://www.memoriasreveladas.gov.br/index.php/ultimas-noticias/649-tj-sp-julga-recurso-docoronel-ustra-contra-condenacao-por-tortura-e-assassinato. Acesso no dia 03 de jan. 2021.
} 
diversos vídeos difundidos por ele, o livro $O$ mínimo que você precisa saber para não ser um idiota, de Olavo de Carvalho (2018).

\begin{abstract}
De acordo com o filósofo Olavo de Carvalho, em entrevista ao Jornal de Brasília, de 28/05/2005, cada capitalista no Brasil, quanto mais ganha, mais dinheiro de dar ao governo e mais dinheiro para a máquina que amanhã vai estrangulá-lo. Conquistada a Presidência da República, o PT, membro fundador do Foro de São Paulo, deveria, até por coerência, se pautar pelas decisões preconizadas pelo Foro. Elas seriam implementadas com cautela, passo a passo, com determinação, até a conquista do objetivo principal - o de tornar o Brasil um país socialista (Ustra, 2018:599-600).
\end{abstract}

Nesse sentido, não apenas a narrativa proferida por Olavo de Carvalho em seus livros, palestras e aulas comercializadas pela internet ${ }^{8}$ evidenciavam uma suposta guerra cultural em curso, que passou a reverberar por diferentes organizações políticas, inclusive por militares de alto escalão que hoje ocupam altos cargos no governo Bolsonaro e, até mesmo, entre grupos jovens, como é o caso do Movimento Brasil Livre - MBL; como parte de suas técnicas orientadas pela ofensa, desqualificação e destruição de reputações através da difusão de mentiras decorrentes daquilo que passou a ser chamado de trollagem ${ }^{9}$, dentre outras técnicas como a "política do apito para cachorro, quando só alguns percebem o chamado, enquanto outros não ouvem nada" (Da Empoli, 2019:153), passaram a ser utilizadas recorrentemente por estes grupos, pois quanto mais radicais construíam os seus discursos orientados pela grande inversão, maior passava a ser o seu alcance, tendo em vista o efeito centrífugo característico da política no século XXI, conforme destacou Da Empoli (2019).

Essa estratégia ofensiva, orientada pela grande inversão e que visa a humilhação do dissidente político, pode ser encontrada no livro intitulado $O$ dever de insultar, em que Olavo de Carvalho (2016:286) sugere de forma generalizante que "sempre que discuto com esquerdistas, sei que estou discutindo com assassinos”. Isso sem falar no entendimento recorrentemente proferido por ele de que "a mentalidade esquerdista tem a tendência compulsiva de sentir-se tanto mais indignada com os outros quanto mais suas próprias culpas aumentam. É o velho preceito leninista: Acuse-os do que você̂ faz, xingue-os do que você̂ é.” (Carvalho, 2018:233)

Assim, segundo Olavo de Carvalho (2018), estaríamos vivendo em meio a uma guerra cultural que visaria impor pautas construídas pelos chamados "globalistas", entendidos como

\footnotetext{
${ }^{8}$ Disponível em https://www.seminariodefilosofia.org/. Acesso no dia 10 de dez. 2020.

9 Trollagem é uma expressão comumente utilizada na internet para zoar, irritar, chatear e até mesmo desqualificar e humilhar outrem, sobretudo um adversário político que não compartilha da mesma visão de mundo.
} 
um desdobramento da esquerda após o final da Guerra Fria, que buscaria impor um Estado universal, comprometendo as demandas nacionais e nacionalistas ${ }^{10}$.

\begin{abstract}
A guerra cultural não é, evidentemente, uma "conspiração", mas a sutileza das suas operações, raiando a invisibilidade, faz com que a impressão confusa suscitada pelo conceito em quem ouça falar dele pela primeira vez seja exatamente essa, produzindo quase infalivelmente aquele tipo de resposta que mereceria o nome de suspicácia ingênua, ou incredulidade caipira. Outra dificuldade é que as armas usadas na guerra cultural são, por definição, uma propriedade quase monopolística da classe dos intelectuais e estudiosos, escapando não só à compreensão como aos interesses do cidadão comum, mesmo de elite, não envolvido em complexos estudos de história literária e cultural, filosofia, linguística, semiologia, arte retórica, psicologia e até mesmo sociologia da arte (Carvalho, 2018:171).
\end{abstract}

Desse modo, para entendermos como foi possível que as manifestações de junho de 2013 no Brasil, iniciadas com os protestos à esquerda capitaneados pelo Movimento Passe Livre - MPL, pudessem ser apropriadas por diferentes grupos das direitas, a exemplo do próprio Movimento Brasil Livre - MBL, dentre outros (Gohn, 2018; Pinheiro-Machado, 2019), é importante compreendermos não apenas a emergência dessas forças políticas a partir do entendimento disso que Olavo de Carvalho (2018) chamou de guerra cultural, orientada pelo que Leirner (2020) chamou de a grande inversão, como também é necessário verificar quais as técnicas produzidas e utilizadas por ele no ciberespaço por meio de uma política orientada por ofensas e humilhações aos dissidentes políticos.

Foi justamente essa técnica utilizada por Olavo de Carvalho - amparada em ofensas, mentiras, destruição de reputação e principalmente voltada para uma espécie de espetacularização midiática via plataformas digitais - que passou a ser incorporada pelos integrantes do MBL através do que chamaram, em entrevista concedida a nós, de estética da zoeira, que consiste na produção e difusão de memes com caráter extremamente ofensivo que busca, no limite, destruir o opositor político. Talvez seja por isso que esses jovens tenham passado a publicar vídeos com os títulos: Kim destrói professor prepotente ${ }^{11}$, Kim humilha de

\footnotetext{
${ }^{10}$ Segundo Olavo de Carvalho (2018:162), “Que o globalismo é um processo revolucionário, não há como negar. E é o processo mais vasto e ambicioso de todos. Abrange a mutação radical não só das estruturas de poder, mas da sociedade, da educação, da moral, e até das reações mais íntimas da alma humana. É um projeto civilizacional completo e sua demanda de poder é a mais alta e voraz que já se viu. Tantos são os aspectos que o compõem, tal a multiplicidade de movimentos que abrange, que sua própria unidade escapa ao horizonte de visão de muitos liberais e conservadores, levando-os a tomar decisões desastradas e suicidas no momento mesmo em que se esforçam para deter o avanço da "esquerda". A ideia do livre comércio, por exemplo, que é tão cara ao conservadorismo tradicional (e até a mim mesmo), tem sido usada como instrumento para destruir as soberanias nacionais e construir sobre suas ruínas um onipotente Leviatã universal. Um princípio certo sempre pode ser usado da maneira errada. Se nos apegamos à letra do princípio, sem reparar nas ambiguidades estratégicas e geopolíticas envolvidas na sua aplicação, contribuímos para que a ideia criada para ser instrumento da liberdade se torne uma ferramenta para a construção da tirania."

${ }^{11}$ Disponível em https://www.youtube.com/watch?v=N5jx5KxKtko. Acesso no dia 03 de jan. 2021.
} 
novo $^{12}$, Deputado do PSOL não lê projeto e passa vergonha ${ }^{13}$, Kim Kataguiri massacra hipocrisia petista ${ }^{14}$, dentre outros que evidenciam como essa prática passou a aglutinar as forças das direitas e destruir as esquerdas, tratando-as de forma homogênea e como se não houvesse conflitos e contradições internas.

Também é importante mencionar a incidência de uma espécie de virada no mercado editorial brasileiro, iniciado principalmente nos anos 2000, com a entrada de Carlos Andreazza na editora Record, em que passamos a constatar a emergência de diversas publicações de autores tributários das direitas, sobretudo, conservadores e/ou liberais, além de distintos livros com conteúdo anti-esquerda e anti-petismo, que passaram não somente a circular por todo o país, mas também a fomentar outras demais publicações com esse mesmo perfil por parte de editoras menores que começam a aparecer, conforme mostrou a pesquisa de Silva (2018).

Nesse sentido, os protestos brasileiros, ocorridos a partir de junho de 2013, não se apresentaram apenas como o princípio das polarizações políticas cada vez mais intensificadas entre as chamadas esquerdas e as direitas, como também possibilitou com que surgisse uma nova era política no país, caracterizada pela atuação das plataformas digitais e seus planos de negócio que visam o engajamento e sua consequente e possível modulação comportamental através de diferentes técnicas, dentre elas, aquilo que Leirner (2020) chamou de a grande inversão, que passou a influenciar na política institucional de grande parte dos países, conforme mostrou o dicionário Oxford em 2016, ao apresentar como palavra a chamada pósverdade.

É importante mencionar que o que estamos chamando de novíssimas direitas decorre do entendimento apresentado por Day (2005) acerca da emergência dos novíssimos movimentos sociais, principalmente no que se refere às suas estratégias de articulação e coalizão política promovidas no ciberespaço. Não obstante, também é importante destacar que Gohn (2019) se refere a estes movimentos que estamos chamando de novíssimas direitas como organizações movimentalistas ${ }^{15}$. Nesse sentido, destacamos dois elementos extremamente significativos para a nossa análise: o primeiro, que trata da insuficiência

\footnotetext{
${ }^{12}$ Disponível em https://www.youtube.com/watch?v=Di8teEKBg-Y. Acesso no dia 03 de jan. 2021.

${ }^{13}$ Disponível em https://www.youtube.com/watch?v=LlPkidVMv-4\&t=35s. Acesso no dia 03 de jan. 2021.

${ }^{14}$ Disponível em https://www.youtube.com/watch?v=oTKU_1jgghc. Acesso no dia 03 de jan. 2021.

${ }^{15}$ Segundo Gohn (2018:121), "Nesses novos grupos destacam-se matrizes teóricas e ideológicas que dão suporte às suas ideias, dentre elas o liberalismo e a doutrina econômica de Hayek e Ludwig von Mises, a defesa do império da lei de Fréderic Bastiat e citações no campo da ciência política de E. Burke e Ortega y Gasset, o Instituto Milenium - fundado em 2006, sediado no Rio de Janeiro, também denominado como o think thank das ideias liberais; e o brasileiro Olavo de Carvalho, transformado em "guru" de vários líderes das organizações movimentalistas".
} 
conceitual acerca do termo "nova direita" cunhado inicialmente por Pierucci (2000), uma vez que a direita mencionada pelo autor, nas duas primeiras décadas do período pósredemocratização do país, se sentia envergonhada ${ }^{16}$ por se reconhecer enquanto tal e estar supostamente associada à censura, prisões, tortura, persecução e até mesmo assassinatos impetrados pelo Estado brasileiro, no contexto da ditadura civil-militar, caracterizando-se pela defesa de uma agenda completamente distinta daquela apresentada pela maior parte das direitas de hoje, a exemplo da hodierna defesa da criminalização do comunismo - PL $5358 / 2016^{17}$ e PL 4425/2020 ${ }^{18}$, ambos propostos pelo filho do presidente, o deputado federal por São Paulo eleito pelo PSL, Eduardo Bolsonaro -, que dificilmente seria defendida naquele contexto de abertura política; enquanto que o segundo elemento se refere às mobilizações ocorridas no ciberespaço, inicialmente capitaneadas por aquilo que tanto Day (2005) e Augusto, Rezende e Rosa (2016) quanto Gohn (2019) chamaram de novíssimos movimentos sociais, recorrentemente associados a grupos que se reconhecem como de esquerda, mas que passaram a ser utilizados como estratégias por diferentes grupos associados à direita de forma bastante semelhante, entretanto, com um alcance muito maior do que os seus opositores esquerdistas.

Junho de 2013 é um marco na vida política e sociocultural brasileira. É quando se inicia um novo ciclo de participação na sociedade brasileira, composto de coletivos e movimentos sociais diversos, com projetos e propostas diferenciadas classificados em três grupos distintos, a saber: clássicos, novos e novíssimos. Os clássicos abarcam os sindicatos, sem-terra, estudantes, movimentos populares/comunitários de bairros, sem teto, etc. Os novos abrangem os movimentos de luta por direitos, identidades etc. criados a partir do final da década de 1970 (gênero, geracionais, étnicos, ambientalistas, etc.); e os novíssimos abrangem movimentos da atualidade, a maioria criados ou "afirmados" na cena pública na década corrente, de 2010, a exemplo do Movimento Passe Livre (MPL) e do Movimento dos secundaristas, de um lado; e de outro o Vem Pra Rua (VPR) e Movimento Brasil Livre (MBL). Aos novíssimos deve-se acrescentar também os coletivos supracitados. Tanto os novos como os novíssimos trabalham com a questão da identidade, mas de forma diferente. Enquanto os novos pautam e constroem a identidade por meio de lutas simbólicas e culturais, pela aquisição ou expansão de direitos, a partir de pertencimentos originários, gênero etc., os novíssimos criam identidades a partir de pautas que envolvem um "fazer", uma ação, uma experiência real, independente de origens etc. (Gohn, 2019:123-124).

\footnotetext{
${ }^{16}$ Pierucci (2000:76), argumenta que "A ocorrência do eleitor direitista envergonhado nas primeiras eleições da Nova República é um dado importante: mostra que a vergonha de si não se restringe às elites da direita radical, mas afeta até mesmo suas bases de voto, e que, portanto, o voto na direita truculenta pode significar, no fundo do 'inconsciente coletivo' das camadas populares, um ato de transgressão impublicável. Daí a frequência com que se encontra, de cima abaixo das hostes da direita, o recurso à dissimulação. Além de astúcia, é vergonha."

${ }^{17}$ Disponível em https://www.camara.leg.br/proposicoesWeb/fichadetramitacao?idProposicao=2085411. Acesso no dia 31 de dez. 2020.

${ }^{18}$ Disponível em https://www.camara.leg.br/propostas-legislativas/2261904. Acesso no dia 31 de dez. 2020.
} 
Embora tenha localizado o nascimento do que chamou de nova direita logo na primeira década do processo de redemocratização ocorrido após o final da ditadura civilmilitar brasileira, as análises trazidas a partir da pesquisa de Antônio Flávio Pierucci (2000) se mostram um tanto quanto limitadas para tratar do contexto contemporâneo caracterizado pela pós-verdade e pela emergência daquilo que estamos chamando de novíssimas direitas. Isso não decorre das limitações de suas análises, ao contrário, elas são bastante precisas e nos permite localizar alguns elementos que possibilitaram a emergência destes grupos políticos hodiernos. No entanto, essa ressalva acerca de sua abordagem se dá em decorrência das mudanças ocorridas nas distintas formas de produção, difusão e circulação de informações engendradas pela internet, sobretudo, a partir de plataformas digitais como o Youtube, que permitiu com que cada um produzisse o seu canal e criasse estratégias de empreendedorismo de si (Foucault, 2008) nos seus perfis disponíveis no ciberespaço.

Além disso, a partir da leitura de Pierucci (2000:58-59), podemos encontrar muitos pontos de convergência entre as novas e as novíssimas direitas, a exemplo da defesa de pautas como a segurança pública, família tradicional, causas anti-igualitárias, anti-feminismo, antihomossexualidade, anti-drogas, dentre outras. No entanto, também encontramos diferenças significativas, principalmente no que se refere à intervenção do Estado na economia, sobretudo, na garantia de direitos fundamentais previstos na Constituição de 1988. Assim, embora tenhamos localizado a presença de um discurso extremamente liberal do ponto de vista econômico presente nas novíssimas direitas, contrariamente ao que víamos com as novas direitas, também constatamos a presença de um conservadorismo radical associado às pautas morais.

O medo e a agressividade em relação aos outgroups, como se sabe não têm nada de novo como ingredientes de síndromes de extrema direita. Não têm nada de novo, é verdade, mas por outro lado conseguem orientar com segurança o diagnóstico do pesquisador quando aponta na direção da extremidade direita do leque político: estamos às voltas com indivíduos arregimentáveis para causas anti-igualitárias radicais e soluções autoritárias de direita. Estranhamente, porém, são favoráveis às greves dos trabalhadores e ao direito de greve, embora não façam greve e tenham cisma de que as greves degenerem bagunça. Defendem a reforma agrária e, deste modo, estão bem longe da bancada ruralista no Congresso Nacional; reprovam, claro, as invasões de terras e a ousadia do MST. Querem gastos públicos com a mesma veemência com que exigem as penas mais severas para o crime. Segurança policial e seguridade social são considerados direitos urgentes de todos os cidadãos decentes e homens de bem: querem sempre e sobretudo a ROTA, emblema das decisões de justiça. Mas querem, também, serviços públicos de saúde, mais escolas, creches, orfanatos, reformatórios, internatos, às vezes campos de concentração com trabalhos forçados, transporte coletivo estatizado, seguro desemprego e aposentadoria condigna, tudo isto e muito mais eles querem do Estado. A cantilena neoliberal anti-welfare compõe o ideário de uma outra direita, não é como eles (Pierucci, 2000:59-60). 
Enquanto as novas direitas vivenciavam aquele momento pós-redemocratização e, portanto, viviam os efeitos ainda presentes das perseguições, censuras e demais formas de violência estatal experimentadas no contexto da ditadura civil-militar, as novíssimas direitas passaram a se articular em uma conjuntura de declínio do governo petista, que acabou sendo alvo da Operação Lava Jato ${ }^{19}$, que procedeu com a prisão do ex-presidente Luiz Inácio "Lula" da Silva ${ }^{20}$, resultando em um processo de desqualificação de políticos e partidos identificados com as esquerdas, retomando uma perspectiva anticomunista, algo que inexistia para as novas direitas, já que, segundo Pierucci (2000:69), naquele momento era como "se o comunismo fosse um cachorro morto" que, como nem susto dá mais, acabou poupando certa agressividade por parte das direitas.

Assim, enquanto que as novas direitas seriam caracterizadas por elementos que, em certa medida, ainda reconheciam a importância da intervenção estatal na economia visando garantir ao menos aqueles direitos fundamentais estabelecidos pela Constituição de 1988, os militantes das novíssimas direitas enxergam qualquer tipo de interferência do Estado no mercado como um problema, inclusive colocando em xeque a própria legalidade da carta magna na medida em que teria sido supostamente produzida por influência de esquerdistas ${ }^{21}$.

Portanto, se as novas direitas ainda defendiam o direito à greve, a reforma agrária (mesmo questionando as invasões do MST), além de gastos públicos com educação, saúde e, principalmente, com segurança pública, conforme mostrou Pierucci (2000), as novíssimas direitas emergentes partirão de uma outra perspectiva, argumentando que a única forma de garantir o bom funcionamento da sociedade se dá pela redução da intervenção do Estado através da adesão às privatizações de todas as empresas que haviam sido criadas para garantir o cumprimento dos direitos fundamentais estabelecidos pela Constituição de 1988, mas que, segundo o $\mathrm{MBL}^{22}$, a imagem negativa desta prática só foi possível porque, "muita gente tem uma imagem negativa da privatização, isso porque os governos petistas gastaram rios de dinheiro para demonizar essa prática que como a gente vai ver só traz benefícios ao país."

Não obstante, é possível encontrar as propostas produzidas e difundidas pelo $\mathrm{MBL}^{23}$ em suas distintas plataformas digitais, toda a sua agenda privatista que vai desde a implementação do sistema de vouchers para ensino básico, fundamental, médio e superior,

\footnotetext{
${ }^{19}$ Disponível em https://www1.folha.uol.com.br/poder/2014/11/1548049-entenda-a-operacao-lava-jato-dapolicia-federal.shtml. Acesso no dia 14 de jun. 2018.

${ }^{20}$ Disponível em https://g1.globo.com/sp/sao-paulo/noticia/lula-se-entrega-a-pf-para-cumprir-pena-porcorrupcao-e-lavagem-de-dinheiro.ghtml. Acesso no dia 14 de jun. 2018.

${ }^{21}$ Disponível em https://www.youtube.com/watch?v=nY6FL5C9vzE. Acesso no dia 30 de jun. 2018.

${ }^{22}$ Disponível em https://www.youtube.com/watch?v=7DrK88jnubA. Acesso no dia 30 de jun. 2018.

${ }^{23}$ Disponível em http://mbl.org.br/wordpress/wp-content/uploads/2017/05/propostas-mbl.pdf. Acesso no dia 30 de jun. 2018.
} 
com valor igual para todos os alunos de cada nível; militarização das escolas em áreas de risco; gestão privada de escolas públicas através de Organizações Sociais e Parcerias PúblicoPrivadas; promoção de competição entre escolas públicas usando métricas como o exame PISA, fazendo parcerias com a iniciativa privada para premiações; desburocratização do processo de abertura de escolas, cursos e do número de vagas em instituições de ensino privadas, assim como de operadoras de planos de saúde; adoção de um sistema de saúde similar ao alemão em substituição ao SUS; obrigatoriedade da contratação de um plano de saúde e fornecimento de plano gratuito para aqueles que não puderem pagar por um; incentivo tributário a empresas que ofereçam planos de saúde a seus funcionários e concessão de benefício tributário a empresas e indivíduos que auxiliem no custeio de hospitais, clínicas e laboratórios de análise; abertura de mercado hospitalar a empresas estrangeiras; privatização dos presídios; privatização de linhas de metrô e VLT e criação de novas linhas por meio de PPPs, dentre muitos outros exemplos.

A caricaturização e até mesmo demonização do Estado e dos governos tratados supostamente como esquerdistas pelo MBL - a exemplo do Partido dos Trabalhadores -, baseando-se na simplificação de toda a complexidade política e econômica a partir de um receituário antiestadista, amparado nas premissas de economistas como Ludwig von Mises ${ }^{24}$, tem sido profetizada como a única solução para os problemas do Brasil, inclusive pelo próprio Olavo de Carvalho ${ }^{25}$. Assim, a saída para o país, segundo os tributários das novíssimas direitas, passando de Olavo de Carvalho à MBL, não se daria por meio de propostas que visassem a garantia dos direitos estabelecidos pela Constituição de 1988, mas sim através da adesão às políticas de austeridade e à entrega da gestão econômica capitaneada pelo Estado à mão invisível do mercado, acreditando que os soberanos nessa sociedade seriam os consumidores. Ou seja, deveríamos crer inquestionavelmente na máxima proferida pelo candidato à presidência da república em 2018 pelo Partido Republicano Brasileiro - PRB, Flávio Rocha ${ }^{26}$, que afirmou - em um evento em que estávamos presentes e que, inclusive, tivemos a oportunidade de entrevistarmos membros do MBL - que "O Estado grande leva a descrença na suprema sabedoria do livre mercado. O livre mercado é o juiz sábio que existe. É a mão de Deus intercedendo sempre a favor do mais competente, do mais eficiente, do mais talentoso". Esse fundamentalismo de mercado, presente na narrativa de Flávio Rocha em evento organizado por grandes empresários de todo o país, em que estavam presentes também

\footnotetext{
${ }^{24}$ Disponível em https://www.youtube.com/watch?v=W1K9yaorlWg. Acesso no dia 30 de jun. 2018.

${ }^{25}$ Disponível em https://www.youtube.com/watch?v=XqA1hjMeKLM. Acesso no dia $31 \mathrm{de} \mathrm{dez.} 2020$.

${ }^{26}$ Disponível em http://mbl.org.br/wordpress/wp-content/uploads/2017/05/propostas-mbl.pdf. Acesso no dia 30 de jun. 2018.
} 
os integrantes do MBL, chega a seu ápice quando o empresário afirma que "a mão do mercado é a mão de Deus".

\section{Estética da zoeira como arma política de desinformação}

Tanto no caso brasileiro quanto no estadunidense as novíssimas direitas potencializaram incessantemente o descrédito nos fatos através de certo entendimento fundamentado na ideia de que estaríamos vivendo sob a égide de uma guerra cultural (Carvalho, 2018), orientada por uma espécie de embaralhamento de fatos e narrativas que possibilitariam a incidência daquilo que Leirner (2020) tratou como a grande inversão, estratégia típica da era da pós-verdade. Nesse sentido, possivelmente estaríamos vivendo em um momento histórico fortemente caracterizado pela desvalorização de conteúdos, dados e informações verificáveis através de métodos, teorias e conceitos que configuram um olhar mais próximo ao da ciência moderna, em detrimento do marketing, possibilitado pelos planos de negócios presentes nas plataformas digitais. Assim, a utilização do marketing, em termos estratégicos, visando a modulação comportamental, acabou se tornando uma realidade não apenas para os negócios, mas também para a política que emerge no século XXI.

Dessa forma, foi a partir de uma resposta proferida pelo membro do MBL, Kim Kataguiri, em entrevista por nós realizada, que pudemos verificar nitidamente certa estratégia amparada na pós-verdade, justamente quando, após perguntado sobre a expansão do MBL nas redes sociais e o porquê de toda essa repercussão, ele respondeu que "É o foco do nosso trabalho que a gente trabalha a forma e não só o conteúdo. A gente deixa a parte de conteúdo para os think thanks lá, dos institutos liberais, tipo Mises e etc... e trabalha a melhor linguagem possível pra fazer não só com que as pessoas entendessem, mas também entendessem porque valia a pena sacrificar um pedaço da vida delas para lutar por aquilo.”

No entanto, o que mais nos chamou a atenção em nossa pesquisa, principalmente no que se tange às estratégias utilizadas pelo MBL, acerca da difusão de seus conteúdos, foi a intencionalidade em relação a mentiras, a exemplo de quando encontramos, em nossa investigação, o relato de um ex-integrante deste movimento e participante, à época, do grupo Estudantes pela Liberdade, Fábio Ostermann, que, em uma entrevista no programa AutentiCidade $^{27}$, relatou que a escolha do nome do vereador paulista e liderança do MBL, Fernando Holiday (DEM), não se deu porque sua mãe adorava a cantora Billie Holiday, conforme cita

\footnotetext{
${ }^{27}$ Disponível em https://www.youtube.com/watch?v=umjN6KNkfuQ. Acesso no dia 13 de jun. 2018.
} 
recorrentemente em entrevistas ${ }^{28}$. Diferentemente disso, foi inspirado no sobrenome do autor de um livro intitulado Acredite, estou mentindo: Confissões de um manipulador das mídias, escrito por Ryan Holiday. Nessa entrevista, Ostermann ainda afirma que este era o livro de cabeceira dos integrantes deste movimento e que este escrito circulava incessantemente entre eles. Segundo o entrevistado, os integrantes do MBL

[...] se especializaram na arte de manipular a mídia, de mentir, de tentar parecer ser
muito maiores do que realmente são. E, de certa maneira, quando a gente fica dando
esse excesso de atenção a eles, a gente acaba jogando o jogo deles. E a esquerda tem
feito isso com uma primazia incrível, uma maestria incrível em fazer o MBL parecer
ser muito maior do que realmente é. O MBL é um bando de moleque. Uma meia
dúzia de oportunistas. E estão lá hoje, enfim, especialmente os irmãos metralha
[Renan e Alexandre Santos] que tem uns duzentos processos trabalhistas nas costas
(Fábio Ostermann, 2017).

A acusação proferida por Fábio Ostermann, em relação aos membros do MBL, sobretudo no que se refere às suas intenções políticas e principalmente acerca das mentiras por eles discursadas no ciberespaço, é facilmente verificável quando realizamos uma breve pesquisa no Youtube. Lá, podemos encontrar diversos vídeos produzidos e compartilhados por seus integrantes que evidenciam a utilização de mentiras em suas publicações a partir do que chamam de estética da zoeira. Um exemplo disso é o vídeo Agrotóxicos salvam vidas ${ }^{29}$, em que Kim Kataguiri tenta argumentar que os alimentos orgânicos são prejudiciais à saúde, diferentemente daqueles que usam produtos químicos, cujo intuito nítido é ridicularizar figuras públicas que defendem um ponto de vista contrário e que certamente representariam uma visão à esquerda.

No entanto, independente da intencionalidade, esse tipo de conduta não é uma característica exclusiva do MBL, uma vez que ela se faz presente em outros diversos formadores de opinião, representantes dessas novíssimas direitas, que atuam nas plataformas digitais, conforme constatamos no vídeo em que Olavo de Carvalho sugere que a Pepsi utiliza células de fetos de bebês abortados para adocicar o refrigerante ${ }^{30}$ e até mesmo na fala proferida por um de seus alunos e seguidores, Allan dos Santos, do canal Terça Livre, que argumenta que a masturbação mata neurônios ${ }^{31}$.

Isso seria cômico se não fosse trágico, tendo em vista que os seus efeitos na política são nefastos, potencializando rupturas nas democracias liberais (Castells, 2018), conforme podemos localizar no vídeo compartilhado por outro aluno de Olavo de Carvalho, Bernardo

\footnotetext{
${ }^{28}$ Disponível em https://www1.folha.uol.com.br/cotidiano/2017/02/1860269-negro-e-gay-vereador-mais-jovemde-sao-paulo-critica-cotas-raciais.shtml. Acesso no dia 13 de jun. 2018.

${ }^{29}$ Disponível em https://www.youtube.com/watch?v=-2kWYWzHM98\&t=4s. Acesso no dia 05 de jan. 2021.

${ }^{30}$ Disponível em https://www.youtube.com/watch?v=714WmFjzDls\&t=3s. Acesso no dia 05 de jan. 2021.

${ }^{31}$ Disponível em https://www.youtube.com/watch?v=yuac0saUf5E. Acesso no dia 05 de jan. 2021.
} 
Kuster, que incentiva os seus seguidores a violentarem fisicamente a filósofa estadunidense Judith Butler $^{32}$ - que de fato foi agredida no aeroporto de Congonhas ${ }^{33}$-, além do vídeo do próprio Olavo de Carvalho que afirma, em meio às eleições presidenciais brasileiras de 2018, que o então candidato à presidência da república pelo PT, Fernando Haddad, havia escrito o livro Em defesa do socialismo, amparado nas ideias de Herbert Marcuse, que assim como o petista, defendia o incesto ${ }^{34}$.Entretanto, diante da desaforada mentira proferida por Olavo de Carvalho $^{35}$, a editora Vozes - que publicou o livro mencionado por ele e é a principal editora brasileira ligada à igreja católica - acabou tendo que disponibilizar uma carta aberta, corrigindo o constrangimento causado pela desinformação apresentada ${ }^{36}$.

Essas práticas descompromissadas com os fatos e mobilizadas pela espetacularização de certo humor violento amparado na transformação do constrangimento do outro, em vídeos ou memes, a exemplo daquilo que os integrantes do MBL chamaram de estética da zoeira, parece ter sido inicialmente desenvolvida no Brasil por Olavo de Carvalho, um dos principais representantes das novíssimas direitas, com enorme reconhecimento da extrema direita internacional ${ }^{37}$. Além disso, se faz necessário recordar que ele exerce uma enorme influência entre os militares brasileiros, conforme podemos verificar em diversas passagens do livro do Coronel Brilhante Ustra (2018), bem como no próprio presidente Jair Bolsonaro, que parece reproduzir recorrentemente essa prática em suas lives, apresentadas em seu canal no Youtube todas as quintas-feiras. Assim, ao visarmos compreender a psicodinâmica, ou seja, esse conjunto de fatores de natureza mental e emocional que motivam certo comportamento humano, por meio da qual opera essa arma política que são as plataformas digitais, podemos

\footnotetext{
${ }^{32}$ Disponível em https://www.youtube.com/watch?v=71348rF17_o. Acesso no dia 05 de jan. 2021.

${ }^{33}$ Disponível em https://g1.globo.com/sao-paulo/noticia/filosofa-judith-butler-e-alvo-de-ofensas-em-aeroportode-sp-e-mulher-e-agredida-ao-defende-la.ghtml. Acesso no dia 05 de jan. 2021.

${ }^{34}$ Disponível em https://www.youtube.com/watch?v=6ee7V-mwGI0. Acesso no dia 05 de jan. 2021.

35 Disponível em https://g1.globo.com/fato-ou-fake/noticia/2018/10/16/e-fake-que-livro-escrito-por-haddadincentive-o-incesto-e-cite-dez-mandatos-do-comunismo.ghtml. Acesso no dia 05 de jan. 2021.

${ }^{36}$ Disponível em https://www.facebook.com/EditoraVozes/photos/a.136691403098937/1517637331670997/. Acesso no dia 05 de jan. 2021.

${ }^{37} \mathrm{Em}$ seu livro intitulado Guerra pela eternidade: O retorno do Tradicionalismo e a ascensão da direita populista, Benjamim Teitelbaum (2020) situa Olavo de Carvalho, assim como Steve Bannon, que atuou como articulista de Donald Trump, nas eleições estadunidense de 2016, em que saiu vitorioso, e Alexandre Dugin, que exerceu enorme influência sob Putin na Rússia, como autores tradicionalistas, ainda que oriundos de tradições distintas. Segundo ele, "O Tradicionalismo, talvez ironicamente, está dando a Bannon, Olavo e Putin um espaço ideológico e uma sanção divina para imaginarem sistemas políticos totalmente novos. O Tradicionalismo declara a sociedade moderna sem sentido, com o argumento de que nossos Estados e nossas comunidades se baseiam cada vez mais apenas na economia e na formalidade burocrática, não na cultura e na espiritualidade. Suas teorias de inversão oferecem justificativas teológicas e escatológicas para a rejeição a instituições que forneçam conhecimento sobre o mundo em que vivemos, ou seja, as universidades e a mídia" (Teitelbaum, 2020: 248). Embora faça uma excelente análise sobre essa articulação da extrema direita populista em nível internacional a partir da classificação de Olavo, Bannon e Dugin como tradicionalistas, o autor acaba por se equivocar ao negar a influência econômica de autores neoliberais como Mises e Hayek, nos textos e aulas de Olavo de Carvalho.
} 
verificar que ela parece fazer com que a ridicularização do outro e a possibilidade de humilhálo publicamente através da produção e difusão de vídeos com conteúdos mentirosos, em uma velocidade jamais vista, desperte uma espécie de engajamento orientado por afetos negativos e segregativos, evidenciando o efeito centrífugo diagnosticado por Da Empoli (2019).

Essa produção audiovisual disponível nas plataformas digitais que passou a ser ampliada por esse tipo de engajamento orientado pelo ódio permitiu certa coalizão destas forças políticas, culminando em um dos maiores veículos de produção de desinformação nas redes sociais, orientadas por aquilo que Leirner (2020) chamou de a grande inversão, que é o site/empresa "Brasil Paralelo", o qual, em seu primeiro vídeo, teve mais de 4 milhões de visualizações $^{38}$. Assim, além de construir uma narrativa alternativa acerca da história do Brasil (Rosa; Ângelo; Mourão; Ferreira, 2020) que reitera a racionalidade colonial ocidêntica presente em grupos conservadores e monarquistas, essa série de vídeos produzidos e comercializados na internet tem sido divulgada tanto por Arthur do Val, em seu canal do Youtube, intitulado Mamaefalei ${ }^{39}$, quanto pelo próprio MBL, em seu canal no facebook ${ }^{40}$, além de também ser propagandeada por Olavo de Carvalho, que é uma das principais referências teóricas destes grupos.

No entanto, considerando a influência de Ryan Holiday (2012) sob o MBL, a ponto de um de seus integrantes incorporar o seu sobrenome, destacamos que, ao reconhecer que sua intenção era ajudar na criação de um sistema de mídia projetado para enganar, persuadir e roubar cada segundo do recurso mais precioso do mundo, o tempo das pessoas, o autor ainda destacou que "o golpe é criar uma marca usando os outros. O que são roubados são sua atenção e sua ingenuidade" (Holiday, 2012:13). Todavia, se faz necessário mencionar um trecho de seu livro, em que o autor evidencia como desenvolvia suas atividades.

Normalmente, trata-se de um trabalho simples. Alguém me paga, eu produzo uma
história para esse cliente e nós a colocamos no sistema - de um blog minúsculo ao
Gawker, do site de um canal de televisão regional ao Huffington Post, aos grandes
jornais e às redes de televisão, até que o irreal se torne real. Às vezes eu começo
plantando uma história. Às vezes eu solto um comunicado de imprensa ou peço a
um amigo para fazer um artigo em seu blog. Às vezes eu "vazo" um documento. Às
vezes eu fabrico um documento e então o vazo. Sério, pode ser qualquer coisa,
desde vandalizar uma página da Wikipédia a produzir um dispendioso vídeo viral.
Não importa como a peça começa, o fim é o mesmo: a economia da internet é
explorada para mudar a percepção do público - vender produtos. Eu não era um
garoto ingênuo quando saí da faculdade para fazer esse tipo de RP em período
integral. Eu já tinha visto o bastante nas guerras de edição da Wikipédia e na política

\footnotetext{
${ }^{38}$ Disponível em https://www.brasilparalelo.com.br/home/. Acesso no dia 30 de jun. 2018.

${ }^{39}$ Disponível em https://www.youtube.com/watch?v=pGyRum3SNKQ. Acesso no dia 30 de jun. 2018.

${ }^{40}$ Disponível em https://www.facebook.com/mblivre/posts/706303486160464?comment_tracking=\%7B\%22tn\%22\%3A\%22O\%2 2\%7D. Acesso no dia 30 de jun. 2018.
} 


\begin{abstract}
dos poderosos usuários de mídia social para saber que algo de questionável acontecia nos bastidores. Parte de mim sabia disso tudo, mas outra parte continuava acreditando. Eu podia escolher os projetos e só trabalhei naqueles em que acreditava - (e, sim, isso inclui American Apparel e Tucker Max). Mas fui sugado pelo submundo dos meios de comunicação, conseguindo picos de divulgação para meus clientes e propagando mais e mais mentiras para fazê-lo. Eu lutava para manter essas duas partes de mim mesmo separadas quando comecei a compreender o ambiente de mídia em que estava trabalhando e que havia algo um pouco mais que errado nele. Isso deu certo até que parou de funcionar para mim. Ainda que eu quisesse poder indicar o momento exato em que tudo veio abaixo, quando foi que percebi que a coisa toda era um golpe gigantesco, eu não consigo. Tudo que sei, é que, em certo momento, aconteceu. Estudei profundamente a economia e a ecologia da mídia online para fazer o meu trabalho bem-feito. Queria entender não apenas como, mas por que aquilo funciona - da tecnologia às personalidades das pessoas que a usam. Estando do lado de dentro eu vi coisas que acadêmicos, gurus e mesmo muitos jornalistas jamais verão. Os editores gostavam de conversar comigo porque eu controlava orçamentos multimilionários de propaganda online, e eles costumavam ser brutalmente honestos. Comecei a fazer ligações entre partes de informação e a ver padrões nessa história. Em livros esgotados há décadas eu li críticas sobre brechas nos meios de comunicação que se abriam novamente. Observava como preceitos psicológicos básicos eram violados ou ignorados por blogueiros quando davam as "notícias". Ao perceber que boa parte da estrutura de publicação online era baseada em suposições errôneas e uma lógica de autointeresse, aprendi que poderia tirar partido dela. Esse conhecimento me assustou e encorajou ao mesmo tempo. Confesso que usei esse conhecimento contra o interesse público para meu próprio ganho (Holiday, 2012:09-10).
\end{abstract}

Esse relato, apresentado por Ryan Holiday (2012), permite-nos compreender como a internet possibilitou a construção de narrativas fundamentadas em fatos que não correspondem com a verdade, mas que, embora não sejam verdadeiros factualmente, a ação produzida discursivamente passa a ter efeito verdade. Essas ponderações podem ser encontradas tanto em escritos de pesquisadores como Robert Merton e sua noção de profecia autorrealizável, que argumenta que "tornamo-nos tais como nos descrevem" (Coulon, 1995:125), quanto nas ponderações trazidas por William Thomas, acerca do chamado "teorema de Thomas", resgatado por Goffman (2012), que afirma que "se as pessoas definem as situações como reais, elas são reais em suas consequências" (Goffman, 2012:23).

Muito além das convocações, as redes sociais passaram a ser usadas para divulgar informações e discutir questões políticas e econômicas, porém de forma bem diferente do que estávamos acostumados a ver nos veículos tradicionais de comunicação. Aliás, a forma se tornou o centro da questão, já que recentemente passamos a encontrar no ciberespaço o aumento significativo da circulação de $m e m e^{41}$ - imagens ou frases com potencial para se

\footnotetext{
${ }^{41}$ Segundo Richard Dawkins (2001) "meme" seria uma espécie de elemento discursivo produzido na cultura humana perpassada por uma unidade de imitação, nascida da expressão "Mimeme", de raiz grega, operada, portanto, de maneira monossilábica e soando um pouco como "gene". Todavia, o autor ainda sugere que essa expressão poderia estar relacionada alternativamente à "memória" ou à palavra francesa même, localizada em exemplos como melodias, ideias, "slogans", modas do vestuário, maneiras de fazer potes ou de construir arcos.
} 
propagar rapidamente pelos meios digitais através de compartilhamentos -, além das fake news, notícias falsas que se tornaram mais frequentes.

Desse modo, a forma-meme se apresenta como um exemplo nítido de como o formato influencia na disseminação de conteúdos na internet. Estratégia que foi e ainda é fortemente explorada pelos clássicos, novos e, principalmente, novíssimos movimentos sociais, dentre eles as novíssimas direitas, que emergem caracterizadas por ideais anti-esquerdistas construídos a partir de forte influência das aulas, cursos e livros de Olavo de Carvalho (2014, 2018), instrumentalizados na produção revisionista acerca da história contemporânea do Brasil.

A atuação do MBL se destaca nas redes e assume essa priorização da forma no lugar do conteúdo, visando convencer o público acerca de suas verdades apresentadas através do que chamaram de estética da zoeira, conforme encontramos na entrevista por nós realizada com Alexandre Santos, Kim Kataguiri e Arthur do Val, todos membros atuantes do MBL. Todavia, Alexandre Santos, em entrevista que nos foi concedida, lembrou que a estratégia já era usada por grupos que se reconheciam como liberais mesmo antes do início das manifestações de junho de 2013. Ele nos relatou sobre o trabalho que executou no comando da candidatura de Paulo Batista (PRP/SP) a deputado estadual em São Paulo, que ficou bastante conhecido por sua campanha que viralizou na internet ${ }^{42}$ através desta forma-meme, em que o candidato aparece voando por uma cidade enquanto soltava o seu "raio privatizador", mostrando a principal bandeira de sua campanha. Renan Starkey, irmão de Alexandre, explica o conceito versado:

\begin{abstract}
A candidatura do Paulo tornou-se maior que nosso grupo ou mesmo que o candidato. Paulo era agora representante de um espectro de pensamento político adormecido em nosso país, o candidato a deputado estadual que mais citações tinha na internet (ranking do sitebeonpop). Num momento em que cada vez mais se fala em "guerra cultural" por parte da esquerda, era de se admirar que através de seu raio, Paulo tivesse resignificado as famigeradas privatizações. Destruindo um trabalho de 20 anos dos estatólatras, pessoas faziam memes privatizando estradas, servidores públicos, políticos desastrados e amigos de escola. Através do raio privatizador, um objeto ou sujeito era convertido de sua versão precária para a versão evoluída. Um feito que faria Mises sorrir (Starkey, 2014) ${ }^{43}$.
\end{abstract}

Embora o mencionado candidato a deputado estadual por São Paulo não tenha sido eleito, os responsáveis por sua campanha, como Renan dos Santos, por exemplo, consideraram que o formato utilizado na divulgação das propostas através da forma-meme, chamada por ele de estética da zoeira, acabou sendo um sucesso e, portanto, se mostrando

\footnotetext{
${ }^{42}$ Disponível em https://www.youtube.com/watch?v=htD7wMjUuhI. Acesso em 26 de jul. 2018.

${ }^{43}$ Disponível em https://renovavinhedo.wordpress.com/. Acesso em 18 de jun. 2018.
} 
extremamente eficaz enquanto uma arma política de desinformação, orientada também por aquilo que Leirner (2020) chamou de a grande inversão.

(...) a gente ganhou muita capilaridade na internet e ficou muito conceituado ali porque era a estética da zoeira como política discutindo um negócio que pra gente era muito caro porque as privatizações sempre foram muito demonizadas e a gente conseguiu inverter o polo (Santos, 2018) ${ }^{44}$.

Assim, foi somente após essa campanha que Alexandre e o seu irmão Renan se juntaram a Kim Kataguiri - jovem que já fazia uso das redes sociais através da utilização de um formato semelhante - para formar o que eles mesmos chamaram de dream team da zoeira. Mas o que seria essa tal estética da zoeira? Renan, que na época da campanha era membro do Movimento Renovação Liberal, explicou que a ideia surgiu do desafio de construir uma candidatura competitiva e polêmica. $\mathrm{O}$ uso da internet enquanto ferramenta da campanha já estava estabelecido, porém a linguagem a ser adotada gerou, inicialmente, debates intensos dentro do próprio grupo.

Eu já havia abordado anteriormente, em minha palestra no I Curso de Formação Política do Renova Vinhedo, em agosto, a existência de uma estética da zoeira que permeava as ações de uma nova geração de liberais brasileiros. Tal estética, advinda de fóruns e "chans" de internet, mescla uma postura anárquica e iconoclasta com montagens toscas e grosseiras e profundas referências a cultura pop. É, enquanto linguagem, uma reação direta à baboseira lobotomizada do universo do politicamente correto. A crença na zoeira é a crença na célebre frase de Marshall McLuhan de que "O meio é a mensagem". Zoamos não apenas porquê a zoeira é cancerígena, mas também porquê nossa mensagem é anárquica, corrosiva e revolucionária. No país do paternalismo cordial, qualquer ativismo libertário é altamente subversivo. Zombar do sistema é sorrir para implodi-lo (Starkey, 2014) ${ }^{45}$.

Desde o início, a preocupação era com a forma da mensagem transmitida, muito mais do que com o conteúdo. A fórmula utilizada inicialmente foi criticada, como afirma Starkey: "mesmo colunistas liberais e conservadores na grande mídia torciam o nariz, afetados pela fórmula. Não havíamos pedido a benção com o rigor devido aos donos do movimento liberal no país. Em suma, cagamos e andamos para todos eles.” (Starkey, 2014) ${ }^{46}$. Ainda hoje, integrando juntos o MBL, reconhecem que vale a máxima de pensar a forma no lugar do conteúdo, como eles mesmos afirmam, deixando a complexidade do debate para ser elaborado pelos think thanks liberais ${ }^{47}$, a exemplo do Instituto Ludwig Von Mises Brasil ${ }^{48}$.

\footnotetext{
${ }^{44}$ Entrevista concedida à Pablo Ornelas Rosa e Tatiana Braga, em 23 de abril de 2018.

${ }^{45}$ Disponível em https://renovavinhedo.wordpress.com/. Acesso em 18 de jun. 2018.

${ }^{46}$ Disponível em https://renovavinhedo.wordpress.com/. Acesso em 18 de jun. 2018.

${ }^{47}$ É importante destacar a tese de doutorado defendida por Camila Rocha, em que a autora constata a relação entre os think thank ultraliberais e sua relação com figuras como Olavo de Carvalho e o próprio MBL. Segundo ela "Apoiados principalmente na popularização das teses defendidas pelo escritor Olavo de Carvalho, a maioria das lideranças, militantes e simpatizantes da nova direita entende que desde a redemocratização e a fundação do Partido dos Trabalhadores, a esquerda, liderada pelo PT, mas que também abrangeria outros partidos como o
} 
Entrevistador(a): O que vocês acham que é a causa dessa expansão toda nas redes sociais? Por que tem essa repercussão toda?

Kim: É o foco do nosso trabalho que a gente trabalha a forma e não só o conteúdo. A gente deixa a parte de conteúdo para os think thanks lá, dos institutos liberais, tipo Mises e etc... e trabalha a melhor linguagem possível pra fazer não só com que as pessoas entendessem, mas também entendessem porque valia a pena sacrificar um pedaço da vida delas para lutar por aquilo. ${ }^{49}$

A estratégia de comunicação utilizada pelo MBL pode ser verificada ao analisar alguns dos discursos disponíveis nas suas plataformas online (Youtube, Instagram, Facebook, etc.), perpassando certa fusão que combina insatisfação com o modelo político dominante nos últimos anos, a saber, o governo petista, além de uma crítica radical ao pensamento de esquerda decorrente de certa leitura antiestadista. Adiciona-se ainda a defesa da família e, para finalizar, a proposição de soluções para acabar com a corrupção, recomendando uma suposta melhoraria no campo econômico do país através da redução paulatina das atribuições do Estado, até alcançar o Estado mínimo. O tempero é dado pelo discurso inflamado, cheio de emoção, com uma pitada de humor ou ironia e a linguagem jovem de fácil entendimento para todos. Ou seja, “tudo é entretenimento”, conforme afirmou Kim em entrevista ${ }^{50}$, reiterando a necessidade da espetacularização, segundo destacou Virilio (2005:24) ao reconhecer que a guerra jamais pode ser separada do espetáculo.

\section{Considerações finais}

Considerando que a política da pós-verdade, em seu estado mais puro, se fundamenta no "triunfo do visceral sobre o racional, do enganosamente simples sobre o honestamente complexo" (D’Ancona, 2018:29), é possível constatar, através da pesquisa por nós desenvolvida, que o que estamos chamando de novíssimas direitas possibilitou justamente o nascimento de uma verdade líquida, efêmera e que pode ser construída a partir do encontro de pessoas e grupos que, mesmo desconhecendo a complexidade dos fenômenos que atravessam

PSDB, teria voltado seus esforços para a construção de uma hegemonia cultural junto à sociedade civil que lhe, possibilitasse conquistar e permanecer no Estado a qualquer custo, daí a soma dos esforços dirigidos a combater o esquerdismo na sociedade civil e o petismo na arena institucional. Em termos teóricos, proponho que as ideias de Olavo de Carvalho, assim como a defesa do ultraliberalismo e da necessidade de intervenção militar, entre outras, começaram a ser difundidas inicialmente a partir da formação de contra- públicos na internet. Durante o auge do lulismo, a defesa destas ideias era realizada muitas vezes por meio de um discurso que combinava agressividade com um humor ácido, ressaltando seu caráter performático. Tal discurso destoava do tom impessoal adotado pelos veículos da grande imprensa e invariavelmente provocava uma reação de choque quando era proferido em públicos dominantes, o que fez com que atores que viriam a ter um papel importante na constituição da nova direita fossem ridicularizados e/ou menosprezados nesta época e adquirissem um status de contra- publicidade. (Rocha, 2019:18-19)

${ }^{48}$ Disponível em https://mises.org.br/. Acesso em 26 de jul. 2018.

${ }^{49}$ Entrevista concedida a Pablo Ornelas Rosa e Tatiana Braga, em 23 de abr. 2018.

${ }^{50}$ Disponível em https://www.youtube.com/watch?v=FiSNvXJYmP4. Acesso em 21 de jul. 2018. 
os fatos narrados, buscam encontrar um meio de tornar verossímil os seus argumentos através de apelos emocionais, independentemente de suas consequências.

Deste modo, é possível verificar que a forma de organização e mobilização articulada pelas redes virtuais no ciberespaço, construída a partir daquilo que Day (2006) chamou de novíssimos movimentos sociais que, no caso brasileiro, se encontrava genuinamente presente no MPL, grupo composto por militantes das mais distintas vertentes das esquerdas, foi capturado pelo MBL, tornando sua capilaridade muito mais potente, tendo em vista também o momento histórico demarcado pelo impeachment contra a ex-presidente Dilma Rousseff (PT), que permitiu um alvo, ainda que impreciso, para direcionar o seu ataque, possibilitando uma espécie de engajamento pelo ódio decorrente do efeito centrífugo, analisado por Da Empoli (2019). Assim, tudo isso só foi possível porque o MBL e antes Olavo de Carvalho, dentre outros, estabeleceram um novo formato a partir do que chamaram de estética da zoeira, possibilitando uma maior difusão de seus conteúdos destinados principalmente aos jovens que não vivenciaram o período da ditadura civil-militar brasileira, e que, portanto, tal lembrança não se fazia presente, tendo em vista que muitos deles não eram nem nascidos naquele momento histórico.

Assim, enquanto que, no contexto das novas direitas, relatadas por Pierucci (2000), a lembrança da ditadura civil-militar brasileira se fazia presente, dificultando e/ou impedindo o reconhecimento de pessoas à direita, tendo em vista que estariam associadas a todo o tipo de violência proferida pelos governos militares, no momento presente, demarcado pelo impeachment da ex-presidente petista, procurou-se e ainda se procura associá-la a uma conspiração globalista capitaneada por uma articulação composta por toda a esquerda internacional, que supostamente visaria acabar com a cultura ocidental. Podemos encontrar isso não apenas nas aulas, mas também nos escritos de Olavo de Carvalho (2014), que passou a ser tratado pela grande parte das novíssimas direitas brasileiras - inclusive pelas próprias forças armadas do país, conforme constatamos no livro de Ustra (2018) - como o grande intérprete do Brasil no último século, através de suas narrativas que aderiam a uma técnica persecutória com aqueles grupos questionadores das mais distintas dimensões da ordem vigente. 


\section{Referências}

AUGUSTO, Acácio; ROSA, Pablo O.; RESENDE, Paulo E. da R. (2016), "Capturas e resistências nas democracias liberais: Uma mirada sobre a participação de jovens nos novíssimos movimentos sociais". Revista Estudos de Sociologia v. 21, n. 40, pp. 21-37 [Consult.09-09-2020]. Disponível em https://periodicos.fclar.unesp.br/estudos/article/view/7581/5792

CARVALHO, Olavo de. (2014), A nova era e a revolução cultural: Fritjof Capra \& Antonio Gramsci. Campinas, Vide Editorial.

CARVALHO, Olavo de. (2016), O dever de insultar: Cartas de um terráqueo ao Planeta Brasil. Campinas, Vide Editorial.

CARVALHO, Olavo de. (2018), O mínimo que você precisa saber para não ser um idiota. Rio de Janeiro, Record.

CASTELLS, Manuel (2000), A sociedade em rede. São Paulo, Paz e Terra.

CASTELLS, Manuel (2018), Ruptura: A crise da democracia liberal. Rio de Janeiro, Zahar.

COULON, Alain (1995), A Escola de Chicago. Campinas, Papirus.

DA EMPOLI, Giuliano (2019), Os Engenheiros do Caos: Como as fake News, as teorias da conspiração e os algoritmos estão sendo utilizados para disseminar ódio e influenciar eleições. São Paulo, Vestígio.

D’ANCONA, Matthew (2018), Pós-Verdade: A nova guerra contra os fatos em tempos de fake News. Barueri, Faro Editorial.

DAY, Richard J. F. (2005), Gramsci is dead: anarchist currents in the newest social movements. Londres, Pluto Press.

DAWKINS, Richard (2001), O Gene Egoísta. Rio de Janeiro, Itatiaia.

DUNKER, Christian I. L. (2019), "Psicologia das massas digitais e análise do sujeito democrático", in S. Abranches, R. de Almeida, A. Alonso. Democracia em risco? São Paulo, Companhia das Letras, pp. 116- 135.

FOUCAULT. Michel (2008), Nascimento da biopolítica. São Paulo, Martins Fontes.

GOFFMAN, Erving (2012), Os quadros da experiência social: uma perspectiva de análise. Petrópolis, Vozes.

GOHN, Maria da G. (2019), Participação e democracia no Brasil: Da década de 1960 aos impactos pós-junho de 2013. Petrópolis, Vozes.

GRAMSCI, Antonio (2002), Cadernos do cárcere. Vol. 5. Rio de Janeiro, Civilização Brasileira.

HOLIDAY, Ryan (2012), Acredite, estou mentindo: Confissões de um manipulador das mídias. São Paulo, Companhia Editora Nacional.

KORYBKO, Andrew (2015), Guerras Híbridas: Da revolução coloridas aos golpes. São Paulo, Expressão Popular. 
LANIER, Jason (2018), Dez argumentos para você deletar agora suas redes sociais. Rio de Janeiro, Intrínseca.

LAZZARATTO, Maurizio (2019), Fascismo ou revolução? O neoliberalismo em chave estratégica. São Paulo, N-1.

LEIRNER, Piero (2020), Brasil no espectro de uma guerra híbrida: Militares, operações psicológicas em uma perspectiva etnográfica. São Paulo, Alameda.

LIND, William (2001), "Fourth-Generation Warfare's First Blow: A Quick Look". Marine Corps Gazzette, v. 85, n. 11 [Consult. 03-01-2021]. Disponível em https://mca-marines.org/magazines/

MACHADO, Débora (2018), “A modulação de comportamento nas plataformas de mídias sociais", in J. Souza, J. Souza, R. Avelino e S. A. da Silveira (Orgs.), A sociedade de controle: Manipulação e modulação nas redes digitais. São Paulo, Hedra, pp. 47-69.

MELLO, Patrícia C. (2020), A máquina do ódio: Notas de uma repórter sobre fake News e violência digital. São Paulo, Companhia das Letras.

PINHEIRO-MACHADO, Rosana; SCALCO, Lucia M. (2018), "Da esperança ao ódio: a juventude periférica bolsonarista", in E. S. Galeggo. O ódio como política: A reinvenção das direitas no Brasil. São Paulo, Boitempo, pp. 55-61.

PINHEIRO-MACHADO, Rosana (2019), Amanhã vai ser maior: O que aconteceu com o Brasil e possíveis rotas de fuga para a crise atual. São Paulo, Planeta do Brasil.

PROUDHON, P-J. (1988), O que é a propriedade? São Paulo, Martins Fontes.

PIERUCCI, Antônio F. (2000), Ciladas da diferença. São Paulo, 34.

ROCHA, Camila (2018), "Menos Marx, mais Mises: Uma gênese da nova direita brasileira (20062018)", Tese (Doutorado em Ciência Política). FFLCH, USP, São Paulo. 233 p.

ROSA, Pablo O. (2016), "Uma ponte para o futuro? Reflexões sobre a agenda neoliberal do governo de transição de Michel Temer em 2016", in P. E. da R. Resende, V. A. de Ângelo (Orgs.), A crise brasileira em perspectiva. Florianópolis, Insular, pp. 137-154.

ROSA, Pablo O. (2019), Fascismo tropical: Uma cibercartografia das novíssimas direitas brasileiras. Vitória, Milfontes.

ROSA, Pablo O., ÂNGElO, Vitor A. de, MOURÃO, Pedro J. C. e FERREIRA, Carolina (2020), "Estratégias de constituição de um novo regime de verdade a partir das produções audiovisuais do Brasil Paralelo: Uma análise sobre o negacionismo", in M. A. M. B. dos Santos e J. E. B. de Miranda. Nova direita, bolsonarismo e fascismo: Reflexões sobre o Brasil contemporâneo. Ponta Grossa, Texto e Contexto.

ROTHBARD, Murray (2013), Manifesto libertário: Por uma nova liberdade. São Paulo, Instituto Ludwig Von Mises.

SILVA, Leonardo Nóbrega da (2018), "O mercado editorial e a nova direita brasileira. In Revista Teoria e Cultura", v. 13, n. 02, pp. 73-84, [Consult. 04-01-2021]. Disponível em file:///Users/pabloornelasrosa/Downloads/12430-Texto\%20do\%20artigo-58567-1-10-20181220.pdf 
STARKEY, Renan. A primeira aventura eleitoral do Movimento Renova. Disponível em https://renovavinhedo.wordpress.com/2014/10/09/\%E2\%98\%86\%E2\%98\%86\%E2\%98\%86-aprimeira-aventura-eleitoral-do-movimento-renova-\%E2\%98\%86\%E2\%98\%86\%E2\%98\%86/

TEITELBAUM, Benjamim R. (2020), Guerra pela eternidade: o retorno do Tradicionalismo e a ascensão da direita populista. Campinas, Unicamp.

TOGNOZZI, Marcelo S. (2014), "A força das Redes Sociais”, in R. Figueiredo (Org.). Junho de 2013. A sociedade enfrenta o Estado. São Paulo, Summus.

VIRILIO, Paul (2005), Guerra e Cinema. São Paulo, Boitempo.

VON MISES, Ludwig (2009), As seis lições. São Paulo, Instituto Ludwig Von Mises.

ZANIN, Cristiano; MARTINS, Valeska e VALIM, Rafael (2019), Lawfare: uma introdução. São Paulo, Contracorrente.

ZUBOFF, Shoshana (2019), The age of surveillance capitalism: The fight for a human future at the new frontier of power. New York, Hachette Book Group. 


\begin{abstract}
This article is product of the articulation of two researches that aims to understand the rise of the newest brazilian rights and the technologies used to spread their worldview. By understanding that the first decades of the 21 st century are being characterized by new ways of producing and disseminating information complements of the cyberspace age, a phenomenon that led the Oxford dictionary to bring 'post-truth' as word of the year in 2016, we saw the need to understand the emergence of the rightwing political traditions, such as the neoconservatives, conservative liberals, liberals and anarchocapitalist libertarians. Thus, this article sought to analyze, from an ethnographic research the forms of production and diffusion of their speeches, as well as their strategies of capillarization in brazilian politics.
\end{abstract}

Keywords: Right, brand newest social movements, MBL, fake News.

\title{
Resumen
}

El artículo es el resultado de la articulación de dos estudios que tienen como objetivo compreender el surgimento de las nuevíssimas derechas brasileñas y las tecnologias utilizadas para difundir su cosmovisión. Entender que las primeras décadas del siglo XXI se están caracterizando por nuevas formas de producción y difusión de la información proporcionada por el ciberespacio, fenómeno que llevó al dicionário de Oxford a trazer como palavra del año la posverdad, vemos la necessidade de entender el surgimento de tradiciones políticas más a la derecha, como los neoconservadores, liberales-conservadores liberales y libertários anarcocapitalistas. Así, el artículo presentado buscaba analizar, a partir de uma investigación etnográfica, las formas de producción y difusión de sus discursos, así como las estratégias de capilarización em la política brasileña.

Palabras-clave: Derecha, Nuevissimos movimentos sociales, MBL, fake News. 